\title{
PAX3-FKHR Fusion Protein Measurement
}

National Cancer Institute

\section{Source}

National Cancer Institute. PAX3-FKHR Fusion Protein Measurement. NCI Thesaurus.

Code C142348.

The determination of the amount of PAX3-FKHR fusion protein present in a sample. 